F. Reprod. Fert. (1974) 37, 239-250

\title{
CERVICAL MUCUS: AN AGENT OR A BARRIER TO CONCEPTION?
}

\author{
EILEEN LINFORD \\ Ministry of Agriculture, Fisheries and Food, \\ Cattle Breeding Centre, Shinfield, Reading RG2 9BZ
}

The significance of the cervix and its secretion, in relation to conception, varies with the species. By natural service, semen deposition in the pig and horse is intrauterine. This is also the site of artificial insemination in cattle even though the semen is deposited in the vagina at natural mating. In these species, therefore, the cervix is by-passed and the cervical mucus can be used only indirectly as an indicator of the stage of the cycle or of the hormonal state of the female. In contrast, in the sheep and in man the semen is deposited in the vagina. Furthermore, human semen is deposited in the female tract at times other than when fertilization can occur. The cervix in these species is involved in the process of conception. The physical and chemical properties of the cervical mucus determine whether the spermatozoa penetrate the cervix and reach the site of fertilization and so the mucus in these species can act either as an agent or as a barrier to conception.

The cervical mucus of most species shows cyclical changes in its physical and chemical properties; these changes are under hormonal control. Most studies of cervical mucus have been concerned with establishing the cyclical variation in mucous components. It is not my intention to present these qualitative and quantitative changes here since this information has already been satisfactorily reviewed (Gibbons \& Mattner, 1966; Weiss, 1970; Schumacher, 1970, 1971; Davajan, Nakamura \& Kharma, 1970; Moghissi \& Blandau, 1972). I wish to consider studies where advantage has been taken of the changing properties of cervical mucus either to improve fertility or to act as a means of contraception.

\section{CERVICAL MUCUS AS A BARRIER TO CONGEPTION}

The impenetrability of cervical mucus to spermatozoa in the human has been recognized for years as a possible cause of infertility. On this premise the postcoital test of cervical mucus was developed (PCT or Sims Huhner test) and is currently used by clinicians in cases of unexplained sterility. A sample of cervical mucus is taken after intercourse and examined microscopically for spermatozoa. Davajan et al. (1970) consider that the examination should take place within $2 \mathrm{hr}$ of coitus and that ten to twenty active spermatozoa/high power field should be found in the mucus for the situation to be normal. In the knowledge that sperm production is normal, if no spermatozoa are present in the mucus, then the cervical mucus is acting as a barrier to sperm penetration. The validity of the PCT in the diagnosis of infertility has been questioned by Gibor, Garcia, Cohen 
\& Scommegna (1970). These workers carried out a large survey and found that the PGT of infertile couples could not be reliably distinguished from that of fertile couples. Nevertheless, a number of in-vitro tests have been developed to avoid the limitations and inconvenience of the PCT. A sample of cervical mucus may be placed on a slide (Guard, 1960) or in a capillary tube (Kremer, 1965) and a sample of semen placed next to it. The penetration of the spermatozoa may then be observed microscopically. By the use of an in-vitro test on cervical mucus obtained from women at mid-cycle, Kunitake \& Davajan (1970) showed that, in the majority of cases, spermatozoa could penetrate easily but the mucus of one woman completely blocked sperm penetration and the mucus from another patient was penetrable but the spermatozoa were immobilized by contact with the mucus. This introduces the possibility of cervical mucus forming either a physical or a chemical barrier to sperm penetration.

\section{Mucus as a physical barrier}

What factors could be responsible for cervical mucus being physically impenetrable? There is only a limited period during a normal cycle when the mucus allows the spermatozoa to penetrate easily. Maximal penetration of human and bovine cervical mucus occurs during the ovulatory phase of secretion with a marked reduction before and after this phase (Roark \& Herman, 1950; Pommerenke, 1962). At this time, oestrogen is dominant and the mucus that is secreted is highly characteristic (Table 1). As soon as progesterone gains dominance the nature of the secretion changes dramatically. Any abnormal hormone

Table 1. Characteristics of cervical mucus in two hormonal states

\begin{tabular}{|c|c|c|}
\hline Property & $\begin{array}{c}\text { Oestrogen } \\
\text { dominance }\end{array}$ & $\begin{array}{l}\text { Progesterone } \\
\text { dominance }\end{array}$ \\
\hline $\begin{array}{l}\text { Volume } \\
\text { Water content } \\
\text { Flow elasticity/spinnbarkeit } \\
\text { Crystallization pattern/ferning } \\
\text { Cell content } \\
\text { Protein content }\end{array}$ & $\begin{array}{l}\text { Maximum } \\
\text { Maximum } \\
\text { Maximum } \\
\text { Maximum } \\
\text { Minimum } \\
\text { Minimum }\end{array}$ & $\begin{array}{l}\text { Minimum } \\
\text { Minimum } \\
\text { Minimum } \\
\text { Minimum } \\
\text { Maximum } \\
\text { Maximum }\end{array}$ \\
\hline
\end{tabular}

balance would be reflected in the properties of the mucus and consequently in its penetrability. Indeed, the nature of the cervical secretion has been predictably changed by the administration of oestrogen or progesterone to an ovariectomized cow (Glover, 1960). In the human, Moghissi (1966) showed that progestagen treatment produced a cervical mucus incompatible with sperm penetration. Thus, the possibility existed of inducing an impenetrable cervical mucus by hormone treatment as a means of contraception.

This possibility is in accordance with our present understanding of the structure of cervical mucus and how it changes with the hormonal milieu. This can be summarized diagrammatically (Text-fig. 1) according to recent work reviewed by Moghissi \& Blandau (1972). Mucus is a hydrogel comprising a glycoprotein framework which supports water and a range of dissolved materials. 
The changing physical properties of the mucus depend on the proportion of glycoprotein: water secreted and the number of cross-linkages in the glycoprotein framework. This is a gross simplification of some very elegant studies carried out on the structure of cervical mucus principally by Odeblad $(1958,1962,1968)$ and Gibbons (1959, 1963, 1964). Recent electron microscopic studies of human cervical mucus (Elstein, Mitchell \& Syrett, 1971) support this structural model.

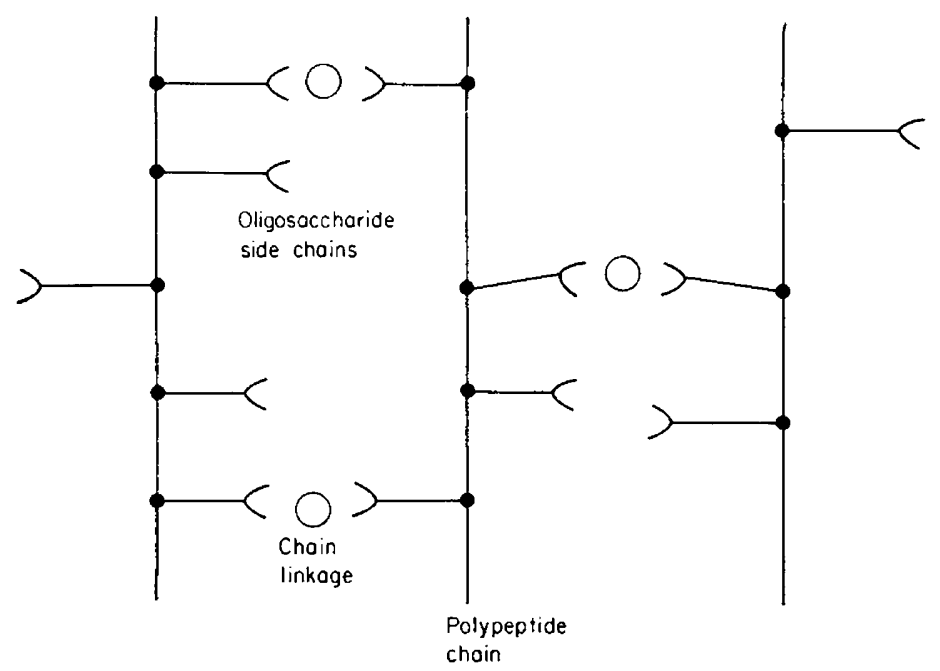

TEXT-Frg. 1. Diagram of the structure of cervical mucus.

An understanding of the structure does, however, reinforce the supposition that progestagen treatment could produce, as one of its effects, a cervical mucus physically hostile to sperm penetration.

Martinez-Manautou, Cortez, Giner, Aznar, Casasola \& Rudel (1966) reported that a continuous low dose of the progestagen, chlormadinone acetate, acted as a contraceptive even though approximately $60 \%$ of the patients receiving this treatment ovulated. Gibor, Cohen \& Scommegna (1969) showed that chlormadinone acetate treatment of infertile women caused cervical mucus changes usually seen in the luteal phase. Roland (1970) showed that spermatozoa were present in the cervical mucus of women treated with Norgestrel but that the spermatozoa were not entering the uterus. More recently, Moghissi \& Marks (1971) examined the effects of microdose Norgestrel treatment on blood hormone levels, cervical mucus properties, vaginal cytology and endometrial histology of normal women. They showed that the treatment caused a reduction in the secretion of cervical mucus, an increase in its cellularity and viscosity and a loss of 'ferning' and spinnbarkeit (the capacity of semi-liquids to be drawn into threads). With one exception, sperm penetration determined by in-vitro tests was effectively inhibited. However, these authors show clearly many other contraceptive effects of Norgestrel treatment and indicate how difficult it is to apportion the significance. Jackson (1961) in a study of women on oral contraceptives showed that their cervical mucus could be either penetrable or impenetrable to 
spermatozoa depending on the proportion of the oestrogenic component in some combination agents.

With an increased understanding of the site and method of mucous secretion, the possibility of contraception by the local administration of hormones still exists. Cohen, Pandya \& Scommegna (1970) attempted this by introducing silastic capsules containing steroids into the cervical canal of women. The results obtained with progesterone were as predicted, but oestradiol or oestrone had no effect on the mucus; this was apparently the result of ineffective release of the oestrogens from the silastic capsule.

In methods used to combat sterility, cervical mucus may inadvertently act as a barrier to conception. An example of this is cited by Graff (1971) who studied the effects of clomiphene citrate therapy to induce ovulation in women. In $16 \%$ of the 228 women studied, he found a mucus characteristic of progesterone dominance. This impaired the method of timing ovulation by standard mucous tests and also sperm penetration. He suggested that the incidence of hostile mucus may account for the discrepancy between the effectiveness of clomiphene to induce ovulation and the lower incidence of pregnancy.

The administration of exogenous progestagen is used to synchronize oestrus in sheep. Smith \& Allison (1971) showed that sheep treated in this way produced significantly less mucus at oestrus than untreated sheep. Mattner (1966) had shown that the mucus in sheep played a rôle essential to the formation of a sperm reservoir in the cervix. The reduction in mucus production by progestagen treatment may account for the reduced fertility of synchronized ewes. Similar reductions in fertility are seen in progestagen-synchronized cattle. Boyd, Gibbons \& Tasker (1972) found no significant effect on the cervical mucus of cows treated in this way, but they conceded that, since the cervix is by-passed in artificial insemination, the mucus could be of no significance to fertility.

\section{Mucus as a chemical barrier}

The possibility of affecting contraception by inducing an immunological response by a woman to semen has been often considered. It is extraordinary that a woman does not become sensitized to seminal plasma proteins as a result of her sexual activity. The suggestion has been made that some proteins are common to cervical mucus and seminal plasma (De Fazio \& Ketchel, 1971) such that the semen would not be recognized as 'foreign'. The immunoglobulins, IgG and IgA, are found in cervical mucus. Tomasi, Tan, Solomon \& Prendergast (1965) showed that the mucous IgA is secretory and distinct from serum IgA. Hulka \& Omran (1969) showed that the IgA was locally produced and biosynthesis of both IgA and IgG by human cervical tissue in vitro has been reported (Moghissi \& Blandau, 1972). This area of investigation may prove to be of significance in the development of a local immunological response against semen.

That the cervical mucus from a woman could immobilize spermatozoa (Kunitake \& Davajan, 1970) suggests the presence of a spermicidal agent in the mucus. Contraception could possibly be achieved by inducing the cervical cells to produce natural spermicidal compounds. Alternatively, spermicidal agents could possibly be introduced systemically so that they are secreted in the mucus. 
This may be feasible since it has been shown that such a route exists for radioactive iodine (Von Kaulla, Aikawa, Bruns \& Wikle, 1957).

\section{GERVICAL MUCUS AS AN AGENT TO CONGEPTION}

The physical and chemical properties of cervical mucus change in response to the hormonal state of the female. Such changes in the mucus can be used as an indicator of the hormonal state or of impending ovulation and, thus, as an agent to conception. A summary of the components and the properties of the mucus used as indicators of ovulation in various species is given in Table 2. Of these

Table 2. Features of cervical mucus used as indicators of ovulation

\begin{tabular}{|c|c|c|}
\hline $\begin{array}{l}\text { Property of mucus used as } \\
\text { indicator of ovulation }\end{array}$ & Species & Reference \\
\hline $\begin{array}{l}\text { Flow elasticity } \\
\text { Spinnbarkeit } \\
\text { Fern pattern } \\
\text { Glucose } \\
\text { Glucose } \\
\text { Chloride } \\
\text { Absorption spectra } \\
\text { Chloride:protein ratio } \\
\text { Chloride } \\
\text { Electroconductivity } \\
\text { Protein } \\
\text { Na/K ratio } \\
\text { Viscosity }\end{array}$ & $\begin{array}{l}\text { Cow } \\
\text { Human } \\
\text { Human } \\
\text { Human } \\
\text { Human } \\
\text { Human } \\
\text { Cow } \\
\text { Cow } \\
\text { Cow } \\
\text { Cow } \\
\text { Human } \\
\text { Pig } \\
\text { Human }\end{array}$ & $\begin{array}{l}\text { Scott Blair, Folley, Malpress \& Coppen (1941) } \\
\text { Cohen, Stein \& Kaye (1952) } \\
\text { Roland (1952) } \\
\text { Birnberg, Kurzrok \& Laufer (1958) } \\
\text { Doyle, Ewers \& Sapit (1960) } \\
\text { McSweeney \& Sbarra (1964) } \\
\text { Choudhury \& Razdan (1967) } \\
\text { Lamond \& Shanahan (1969) } \\
\text { Bishop, Macdonald \& Smith (1969) } \\
\text { Sopeljnik (1969) } \\
\text { Elstein \& Macdonald (1970) } \\
\text { Haynes (1971) } \\
\text { Billings, Billings, Brown \& Burger (1972) }\end{array}$ \\
\hline
\end{tabular}

methods, the clinician still uses the spinnbarkeit and fern pattern of the mucus routinely to determine the mid-cycle in women. However, there is still no objective, reliable method of predicting ovulation in animals. An increasing demand from the farming industry for help with the problem of heat detection in cattle led us to investigate bovine cervical mucus with the intention of using a component as an indicator of oestrus.

Lucas, Neufeld, Utterback, Martin \& Stotz (1955) had shown that the administration of oestrogen to the rat caused a 200 -fold increase in the peroxidase content of the uterus. Klebanoff \& Smith (1970) and Smith \& Klebanoff (1970) established that the rat uterine fluid and cervical secretion contained a peroxidase-mediated antimicrobial system. Peroxidase would be a convenient indicator as it is an enzyme with well defined methods of qualitative and quantitative detection. The essential requirement is that the change in enzyme content of the mucus at or before oestrus is of such a magnitude that methods designed for its detection can be relatively insensitive. This could then permit a degree of individual variation which has been the cause of failure of other methods of detecting oestrus.

Cervical mucus samples were collected daily by means of a sucking-tube from seven maiden heifers through one oestrous cycle. At the time of sampling, the ovaries of each animal were examined by rectal palpation to establish the changes 
in size of the follicles and corpora lutea. The occurrence of oestrus was also established by observation of the animal's behaviour.

A rapid dispersion of the mucus could be achieved by the addition of 0.05 M-dithiothreitol but this reagent interferes with the method of assay of peroxidase. The most satisfactory method was found to be the physical dispersion of the mucus in water by means of a Potter-Elvejehm homogenizer. Aliquots of this dispersed mucus were then assayed for peroxidase by following the oxidation of guaiacol at $436 \mathrm{~nm}$ in a spectrophotometer. Total protein was also determined by the use of the biuret reagent. Corrections could be made for the dilution of the mucus so that the enzyme and protein could be expressed per gram of mucus collected.

The results obtained for one animal are given in Text-fig. 2. The peroxidase content of the mucus fluctuates throughout the cycle but drops to very low levels

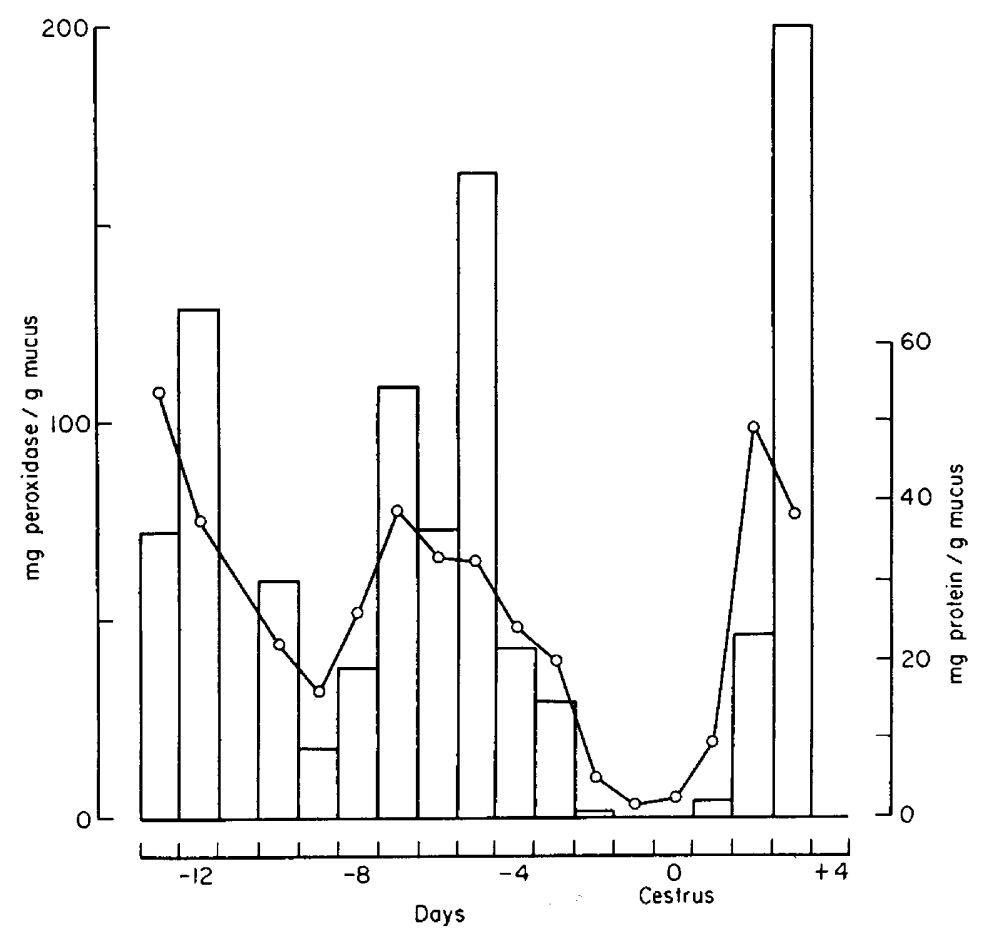

TEXT-Fig. 2. Peroxidase and protein content of cervical mucus from a heifer throughout one oestrous cycle. Columns: peroxidase; lines: protein.

for 2 days before ovulation. The day of oestrus when the animal stands to the bull is 16 to $18 \mathrm{hr}$ before ovulation. This 'trough' in peroxidase content is marked and was shown by six of the seven animals. In the single animal in which no disappearance of the enzyme occurred (Text-fig. 3), no oestrous behaviour was observed. This animal was inseminated at a later date but did not hold to that insemination.

The protein content of the cervical mucus follows a pattern similar to that of peroxidase (Text-figs 2 and 3 ). The minimal levels of protein in cervical mucus at oestrus have already been established (Elstein, 1970; Hamana, El-banna \& 
Hafez, 1971). The decrease in peroxidase at oestrus, however, was contrary to the result predicted by the studies in other animals. It cannot be accounted for by the increase in water content of the oestrous mucus, as the spectrophotometric assay is extremely sensitive and the dilution effect is not great.

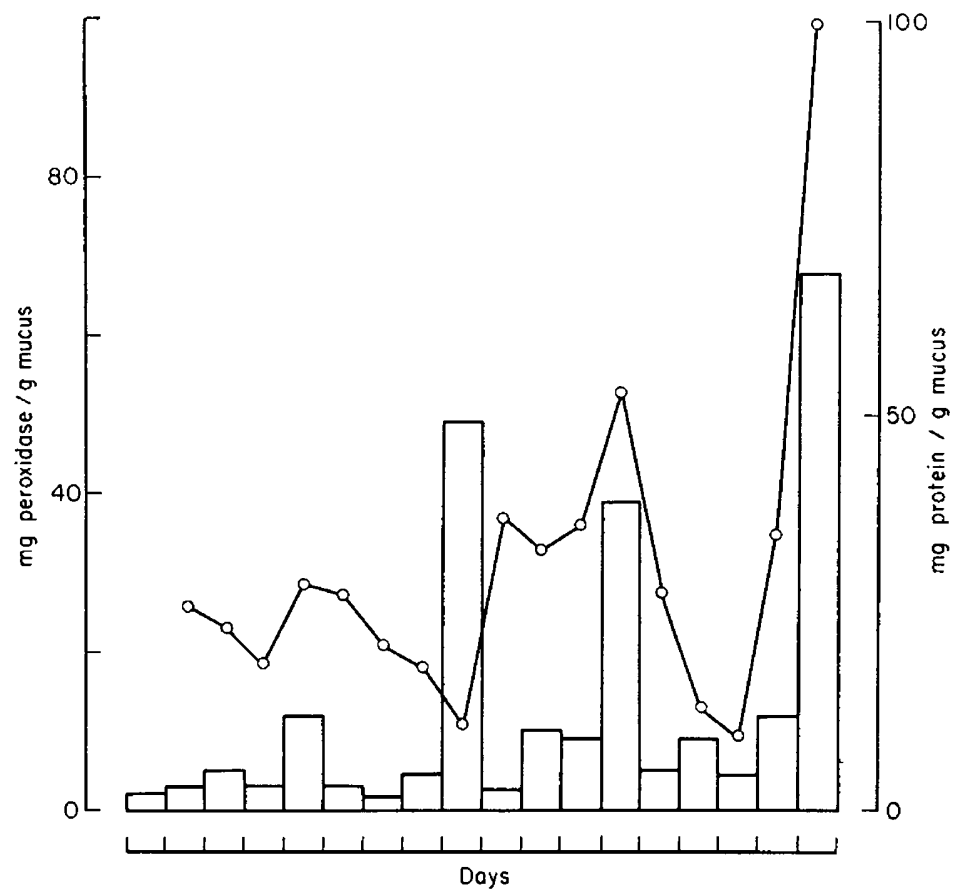

TEXT-Fig. 3. Peroxidase and protein content of cervical mucus from a heifer which showed no oestrous behaviour.

If this change in peroxidase content of cervical mucus is to be used as an indicator of oestrus it is essential to establish that it is hormonally controlled. Oestrus was induced in two ovariectomized heifers by an intramuscular injection of $400 \mu \mathrm{g}$ oestradiol benzoate. Behavioural oestrus was manifest 15 to $20 \mathrm{hr}$ after this treatment. The flow of mucus increased at the induced oestrus in the same way as it increases at a natural oestrus. Assays of peroxidase were carried out on mucus samples collected from these two ovariectomized heifers throughout the induced oestrous period. The results mimicked those obtained in the intact animal; as long as a typically oestrous mucus was produced, the level of peroxidase was negligible but before oestrogen treatment the mucus was scant and contained peroxidase in variable amounts.

Milk is known to contain a peroxidase, lactoperoxidase (Saunders, HolmesSiedle \& Stark, 1964). Peroxidase is also a constituent of other body secretions such as saliva. It is not surprising, therefore, to find it in cervical mucus but it is difficult to explain the significance of the cyclic variation of this enzyme.

The use of cervical mucus as an indicator of oestrus presents a number of practical problems, so the finding that the peroxidase content of cows' milk was significantly higher at oestrus (Kern, Wildbrett \& Kiermeier, 1963) deserved 
further investigation; testing milk is easier than testing cervical mucus. Samples of milk $(10 \mathrm{ml})$ were obtained in the middle of the morning milking from each of two cows for 25 days. The milk was centrifuged to remove the fat and then assayed spectrophotometrically for peroxidase and protein. The days of oestrus were known for the two animals but the results obtained (Text-fig. 4) show that there is random variation in the enzyme content of the milk. No indication of oestrus could be given by the level of peroxidase or protein in the milk.

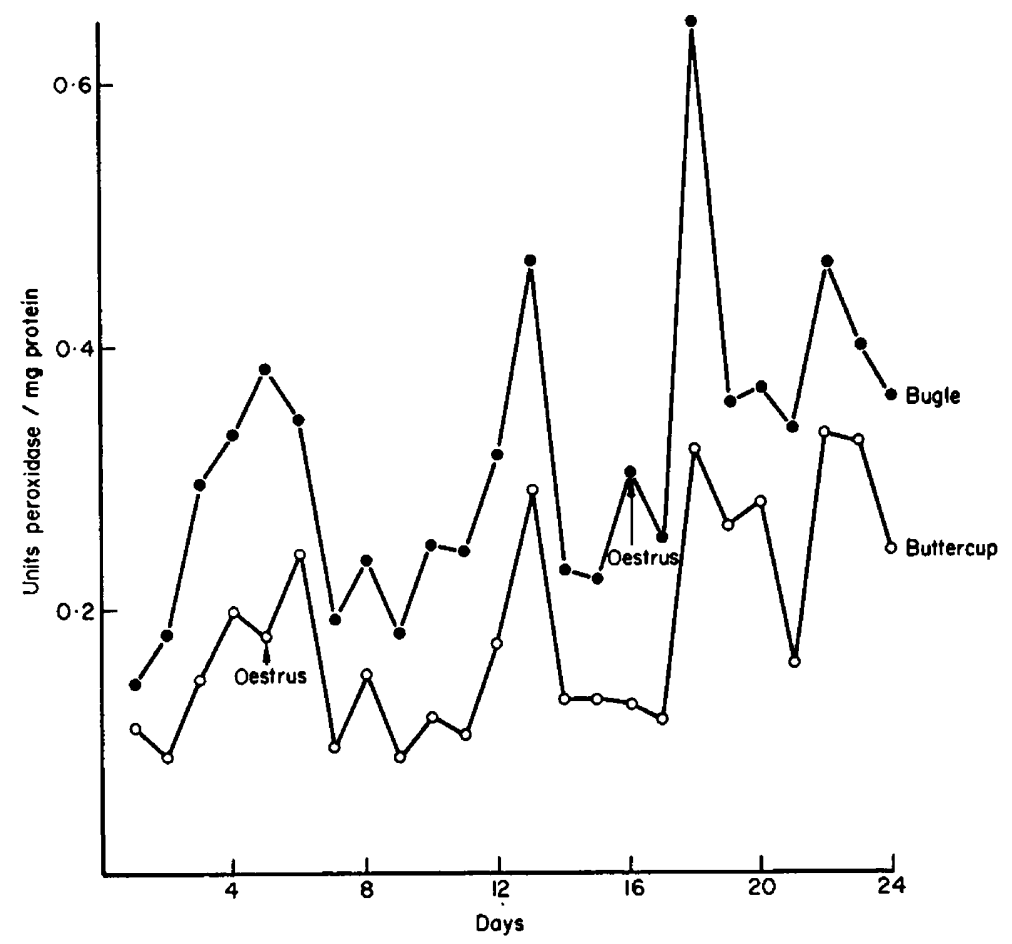

Text-Frg. 4. Peroxidase content of milk from two cows during the oestrous cycle.

The possibility that this enzyme is involved in an anti-bacterial system has been suggested by Smith \& Klebanoff (1970). Enhörning, Huldt \& Melen (1970) showed that human cervical mucus had minimal anti-bacterial action at mid-cycle. This rôle for the peroxidase of cervical mucus has yet to be investigated. Peroxidase is an enzyme found in leucocytes. During the luteal phase of the cycle in the cow the cervical mucus contains leucocytes and other cellular material, but this cellularity of the mucus is minimal at oestrus (Table 1). The gross changes in the peroxidase content of the mucus can be linked visually with the cell content of the mucus. One heifer developed endometritis and samples of cervical mucus collected at oestrus supported an enormous population of leucocytes; the peroxidase levels were correspondingly high. Occasionally, the mucus at oestrus contained no cells but possessed a low peroxidase activity; this may be the enzyme intrinsic to the cervical secretion. 
The development of a test for bovine oestrus

The essential requirements of a test for bovine oestrus are: prediction or confirmation of the day of oestrus; reliability despite individual variation; simplicity of operation so that it may be used by untrained personnel; safety to animals and operators.

The relatively refined laboratory techniques of assaying peroxidase had now to be replaced by a simple means of testing the cow reproductive tract for this enzyme. The most successful method of testing was found to be by the use of a finger stall. Gauze finger stalls were treated with chemicals so that on contact with peroxidase they turned bright red. The finger bearing such a stall was inserted to the full extent into the vulva of the heifer and rotated against the wall of the vagina and then removed. If the stall turned red, peroxidase was present and the animal was not on heat, whereas, if the stall remained uncoloured, the animal was in oestrus. Frequently, at this latter stage, mucus would be seen on the finger stall when it was removed. When tested on twenty maiden heifers, this method of detection was found to be reliable, safe and simple to operate. It therefore satisfied the requirements of a method for detecting oestrus, and a provisional patent was lodged (Patent No. 20845/72).

It was important at this stage to test the method exhaustively on a sample of cows on farms with no apparent problems of heat detection. To do this the co-operation of eight local farmers was achieved. These were farms where the cows were tethered for milking. Sixty-one cows of various breeds which had calved 21 to 40 days before the start of the trial were used in the experiment. Finger stalls were prepared in the laboratory each day so that a test of storage of the stalls was not confused with a test of effectiveness of the method. These sixty-one cows were tested by finger stall before or after milking each day for 30 days. The testers were instructed to collect cervical mucus from cows for which a positive test (i.e. no colour) was obtained or from any animal known to be in oestrus irrespective of the test result. These samples of mucus were then brought back to the laboratory and assayed for peroxidase and protein.

A summary of the results obtained in this trial is shown in Table 3. One

Table 3. Results of the field test of the peroxidase indicator of bovine oestrus

\begin{tabular}{l|c|c|c|c}
\hline & $\begin{array}{c}\text { Oestrus } \\
\text { Days 0 to 1 }\end{array}$ & Days 2 to 6 & $\begin{array}{c}\text { Dioestrus } \\
\text { Days 7 to 16 }\end{array}$ & Days 17 to 21 \\
\hline No. of positive tests/no. of tests & $6 / 66$ & $1 / 330$ & $3 / 660$ & $2 / 330$ \\
Peroxidase content of mucus & 0.080 & $4 \cdot 808$ & 3.007 & $1 \cdot 232$ \\
$\quad$ samples mg/g mucus (S.D.) & $(0 \cdot 203)$ & $(14 \cdot 368)$ & $(6.426)$ & $(0.907)$ \\
Protein content of mucus & $3 \cdot 12$ & 16.65 & 21.94 & $10 \cdot 88$ \\
samples mg/g mucus (S.D.) & $(1 \cdot 86)$ & $(2 \cdot 55)$ & $(11.37)$ & $(14.28)$ \\
\hline
\end{tabular}

animal was sold during the trial so that the total tested was sixty. No definite oestrous behaviour records were obtained for seven cows. So there were sixty-six definite oestrous periods to test. It will be seen from the results that of those sixty-six only six were detected by a positive reaction to the finger stall. The samples collected at this time showed that the peroxidase was very low indeed, 
especially when it is considered that only ten samples gave any enzyme reaction at all even with a very sensitive assay method. The protein of the mucus at this time was also very low. The remainder of the oestrous cycle has been divided into three parts merely to give more information about the days before and after oestrus when false positives in a test would be disastrous. It can be seen that there were 1320 tests carried out and of these six were false positives. It will also be seen that the peroxidase content and protein content of the mucus was of a different order of magnitude at times other than at oestrus.

The reason for the failure of the test in cows appears to be one of anatomy. The assays of the mucus collected during the trial confirmed the results obtained for the heifers (Text-fig. 2) so the principle of the test remains correct. In the heifer, the orientation of the cervix to the vulva is such that mucus produced at the cervix flows out at the vulva and frequently hangs from the vulva; farmers refer to it as a 'bulling string'. When the cow has calved several times the cervix is lower relative to the vulva and even though the cervical mucus is produced at oestrus it frequently does not flow from the vulva but remains as a pool in the anterior vagina from where it will be reabsorbed. To obtain cervical mucus samples the testers were lifting the cervix to align the sampling tube per rectum. When the cervix was raised in this way the mucus would then reach the vulva but unless the mucus bathed the vulva there was sufficient peroxidase there to give a false negative reaction. It is now apparent that to obtain satisfactory detection in the cow it is necessary to penetrate the tract further. Such a device will have to be simple in design so that untrained personnel may use it without risk of damage to the reproductive tract. The low incidence of false positives in this trial encourages the continuation of this investigation.

The application of this test to other species is also in progress. The production of cervical mucus by the sheep and human is similar to that of the cow so the probability of success in these species is higher. The pig could only be satisfactorily tested by this method during the oestrous period when the animal is co-operative. It remains to be determined whether a limited period of optimal mating or insemination during the $48-\mathrm{hr}$ oestrus of the pig can be recognized by this method.

\section{GONCLUSION}

I hope that it is now clear how the cervical secretion can, in itself, form a barrier or be an aid to conception and how it can be manipulated to serve as a contraceptive or as an indicator of the time at which mating could give the highest chance of conception. Studies of reproduction and fertility tend to divide into two camps, those for and those against conception. The study of cervical mucus shows that, if an understanding of the process of conception can be achieved, it can readily be applied either to combat fertility or to enhance it.

\section{ACKNOWLEDGMENTS}

I wish to acknowledge the help of Mr I. B. Munro and Mr C. O'Hagan with the collection of cervical mucus samples; Mr G. D. Palmer, Mr J. T. Dingley, Mr A. J. Davis, Mrs J. Iosson and Mrs R. E. Winder with the field trial; and Dr H. L. Buttle of the National Institute for Research in Dairying for the surgery. 


\section{REFERENCES}

Billings, E. L., Billings, J. J., Brown, J. B. \& Burger, H. G. (1972) Symptoms and hormonal changes accompanying ovulation. Lancet, $\mathbf{i}, 282$.

Birnberg, C. H., Kurzrok, R. \& Laufer, A. (1958) Simple test for determining ovulation time. F. Am. med. Ass. 166, 1174.

Bishop, E.J. B., Macdonald, D. A. \& Smith, D. W. W. Q. (1969) The use of silver chromate-impregnated paper for oestrus detection in cows. Proc. S. Afr. Soc. Anim. Prod. 8, 2071.

Boyd, L. J., GibBons, R. A. \& TASKER, J. B. (1972) Characteristics of cervical mucus from progestagentreated cattle. Br. vet. J. 128, 260.

Choudhury, P. N. R. \& RAZDAN, M. N. (1967) Absorption spectra of cervical mucus of cows. Zootec. Vet. 22, 273.

Cohen, M. R., Pandya, G. N. \& Scommegna, A. (1970) The effects of an intracervical steroid-releasing device on the cervical mucus. Fert. Steril. $21,715$.

Cohen, M. R., Stein, I. F. \& Kaye, B. M. (1952) Spinnbarkeit: a characteristic of cervical mucus. Fert. Steril. 3, 201.

Davajan, V., Nakamura, R. M. \& Kharma, K. (1970) Spermatozoan transport in cervical mucus. Obstetl gynec. Surv. 25, 1.

De Fazio, S. R. \& KeTChel, M. M. (1971) Immuno-electrophoretic analysis of human cervical mucus and seminal plasma with an antiserum to cervical mucus. F. Reprod. Fert. 25, 11.

Doyle, J. B., Ewers, F. J. \& SAPIT, D. (1960) The new fertility testing tape. A predictive test of the fertile period. F. Am. med. Ass. 172, 1744.

Elstein, M. (1970) The proteins of cervical mucus and the influence of progestagens. F. Obstet. Gynaec. Br. Commonw. 77, 443 .

Elstein, M. \& Macdonald, R. R. (1970) The relation of cervical mucus proteins to sperm penetrability. 7. Obstet. Gynaec. Br. Commonw. 77, 1123.

Elstein, M., Mitchell, R. F. \& SyretT, J. T. (1971) Ultrastructure of cervical mucus. F. Obstet. Gynaec. Br. Commonw. 78, 180.

Enhörning, G., Huldt, L. \& Melen, B. (1970) Ability of cervical mucus to act as a barrier against bacteria. Am. 7. Obstet. Gynec. 108, 532.

Grbeons, R. A. (1959) Chemical properties of two mucoids from bovine cervical mucin. Biochem. 7. 73, 209.

Gibrons, R. A. (1963) The sensitivity of the neuraminosidic linkage in microsubstances towards acid and towards neuraminidase. Biochem. F. 89, 380 .

GibBons, R. A. (1964) Le mucus cervical : propriétés chimiques et physiques et quelques observations sur le comportement des spermatozoïdes dans la sécrétion. In: Les Fonctions du Col Uterin, p. 57. Masson, Paris.

Grbions, R. A. \& MAtrNer, P. (1966) Some aspects of the chemistry of cervical mucus. Int. F. Fert.11, 366.

Gibor, Y., Cohen, M. R. \& Scommegna, A. (1969) Effect of continuous administration of small doses of chlormadinone acetate on the cervical mucus and postcoital test. Fert. Steril. 20, 572.

Gibor, Y., Garcia, C. J., Cohen, M. R. \& Scommegna, A. (1970) The cyclical changes in the physical properties of the cervical mucus and the results of the postcoital test. Fert. Steril. $21,20$.

GLover, F. A. (1960) The effect of ovarian hormone administration on the consistency of cervical secretion in the cow. F. Reprod. Fert. 1, 110.

GRAFF, G. (1971) Suppression of cervical mucus during clomiphene therapy. Fert. Steril. 22, 209.

GUARD, H. R. (1960) New technique for sperm-mucus penetration tests using a hemocytometer. Fert. Steril. 11, 392.

Hamana, K., El-Banna, A. A. \& Hafez, E. S. E. (1971) Sialic acid and some physicochemical characteristics of bovine cervical mucus. Cornell Vet. 61, 104.

Haynes, N. B. (1971) Changes in pig cervical mucus in relation to the oestrous cycle. F. Reprod. Fert. 27, 211.

Hulka, J. F. \& Omran, K. F. (1969) The uterine cervix as a potential local antibody secretor. Am. $\mathcal{F}$. Obstet. Gynec. 104, 440.

JACKson, M. H. (1961) Observations on the use of certain orally active progestogens for the control of fertility in women. Proc. R. Soc. Med. 53, 433.

Kern, V. R., Wildbrett, G. \& Kiermeier, F. (1963) Abhängigkeit der Peroxydase-Aktivität in Milch vom Sexualzyklus beim Rind. Z. Naturf. 18, 1082.

KLebanoff, S. J. \& Smrth, D. C. (1970) The source of $\mathrm{H}_{2} \mathrm{O}_{2}$ for the uterine fluid-mediated sperminhibitory system. Biol. Reprod. 3, 236.

KREMER, J. (1965) A simple sperm penetration test. Int. F. Fert. 10, 201.

Kunitake, G. \& Davajan, V. (1970) A new method of evaluating infertility due to cervical mucusspermatozoa incompatibility. Fert. Steril. 21, 706. 
Lamond, D. R. \& Shanahan, A. G. (1969) Chemical changes in cervical mucus from normal and ovariectomized cows treated with hormones. Biol. Reprod. 1, 335.

Lucas, F.V., Neufeld, H. A., Utterback, J.G., Martin, A.P.\& Stotz, E. (1955) The effect of oestrogen on the production of a peroxidase in the rat uterus. 7. biol. Chem. 214, 775.

McSweeney, D. J. \& Sbarra, A. J. (1964) A new cervical mucus test for hormone appraisal. Am. F. Obstet. Gynec. 88, 705.

Martinez-Manautou, J., Cortez, V., Giner, J., Aznar, R., Casasola, J. \& Rudel, H. W. (1966) Low doses of progestogen as an approach to fertility control. Fert. Steril. 17, 49.

MATTNER, P. E. (1966) The cervix and its secretion in relation to fertility in ruminants. $\mathrm{Ph} . \mathrm{D}$. thesis, University of Reading.

Moghissi, K. S. (1966) Cyclic changes of cervical mucus in normal and progestin-treated women. Fert. Steril. 17, 663.

Moghissi, K. S. \& Blandau, R. J. (1972) Biology of the cervix. F. reprod. Med. 8, 21.

Moghissi, K. S. \& MARKs, C. (1971) Effects of microdose Norgestrel on endogenous gonadotropic and steroid hormones, cervical mucus properties, vaginal cytology, and endometrium. Fert. Steril. 22, 424.

OdebLad, E. (1958) The physics of the cervical mucus. Acta obstet. gynec. scand. 38, Suppl. 1, 44.

OdEBLAD, E. (1962) Undulations of macromolecules in cervical mucus. Int. F. Fert. 7, 313.

Odeblad, E. (1968) The functional structure of human cervical mucus. Acta obstet. gynec. scand.47, Suppl. $1,57$.

Pommerenke, W. T. (1962) Some biochemical aspects of the cervical secretions. Ann. N.Y. Acad. Sci.97, 581.

Roark, D. B. \& Herman, H. A. (1950) Physiological and histological phenomena of the bovine estrual cycle with special reference to vaginal-cervical secretions. Res. Bull. Mo. agric. Exp. Stn, No. 455.

RoLAND, M. (1952) A simple test for the determination of ovulation, estrogen activity, and early pregnancy using the cervical mucus secretion. Am. F. Obstet. Gynec. 63, 81.

Roland, M. (1970) Prevention of sperm migration into the uterine cavity by a microdose progestagen. Fert. Steril. 21, 211.

Saunders, B. C., Holmes-Siedle, A. G. \& Stark, B. P. (1964) Peroxidase. Butterworths, London.

Schumacher, G. F. B. (1970) Biochemistry of cervical mucus. Fert. Steril. $21,697$.

Schumacher, G. F. B. (1971) Soluble proteins in cervical secretions. In: Pathways to Conception. The Role of the Cervix and the Oviduct in Reproduction, pp. 168-187. Ed. A. I. Sherman. Charles C. Thomas, Springfield, Illinois.

Scott Blair, G. W., Folley, S. J., Malpress, F. H. \& Coppen, F. M. V. (1941) Variations in certain properties of bovine cervical mucus during the oestrous cycle. Biochem. F. 35, 1039.

Smith, D. G. \& Klebanoff, S. J. (1970) A uterine fluid-mediated sperm-inhibitory system. Biol. Reprod. 3,229 .

Smith, J. F. \& Allison, A. J. (1971) The effect of exogenous progestagen on the production of cervical mucus in the ewe. F. Reprod. Fert. 24, 279.

SopeljNiK, V. M. (1969) Measuring electroconductivity of cervical secretions for determination of optimum insemination time in cows. Moloch-m'yas. Skotarst. Kÿyiv, 16, 87. (Anim. Breed. Abstr. 39, 492).

Tomasi, T. B., Tan, E. M., Solomon, A. \& Prendergast, R. A. (1965) Characteristics of an immune system common to certain external secretions. F. exp. Med. 121, 101.

Von Kaulla, K. N., Aikawa, J. K., Bruns, P.D. \& Wikie, W. T. (1957) Secretory function of the human uterine cervix. Studies with radioisotopes. Fert. Steril. 8, 444.

WEIss, G. (1970) Effect of steroid hormones on cervical mucus. In: Advances in Steroid Biochemistry and Pharmacology, Vol. 1, pp. 137-163. Ed. M. H. Briggs. Academic Press, New York. 